\title{
28. PHYSICAL PROPERTIES OF SEDIMENTS FROM THE NANKAI TROUGH, DEEP SEA DRILLING PROJECT LEG 87A, SITES 582 AND 5831
}

\author{
Cynthia J. Bray and Daniel E. Karig, Department of Geological Sciences, Cornell University²
}

\begin{abstract}
Physical properties measured in the sediments of two sites drilled in the toe of the accretionary prism of the Nankai Trough are reviewed, interpreted, and compared with the results from Leg 31. The in situ logging program demonstrates that the trench wedge sequences drilled at both Sites 582 and 583 are composed of approximately $50 \%$ sand- and siltrich units, which are interbedded with the clay-rich strata that constitute 75 to $85 \%$ of the sediment recovered during coring. Lithologic variation, particularly composition and grain size, significantly affect the physical properties of the sediments. A consistent shear-strength-porosity relationship is found in all the cored sequences, suggesting that at shallow depths shear strength is primarily controlled by the porosity of the sediments. At low porosities, chemical or mechanical processes other than loss of water may contribute to the continual increase in shear strength. Porosity profiles and consolidation tests from Sites 582 and 583 refute previous interpretations of the Leg 31 results, which according to the sediments of the Nankai Trough become highly overconsolidated within increasing depth. Instead, the trough-fill sediments of the Nankai wedge, to depths of $550 \mathrm{~m}$, exhibit only slight dewatering resulting from tectonic stresses. Dewatering of tectonically deformed sediments is interpreted to result from three processes: uniaxial (vertical) consolidation induced by sedimentation and tectonic thickening, diffuse prefailure shear deformation, and heterogeneous shear deformation accompanying high postfailure strains along shear zones.
\end{abstract}

\section{INTRODUCTION}

A principal objective of Leg $87 \mathrm{~A}$ was to investigate the change in physical and mechanical properties associated with subduction and accretion processes. The Nankai Trough is an excellent location for this project because high-quality reflection profiles (Nasu et al., 1982) clearly reveal the large-scale structural style and geometry, allowing the correlation of physical properties with structural features.

The drilling program for the Nankai Trough included two sites. Site 582 , located $2 \mathrm{~km}$ seaward of the deformation front, was planned to obtain "reference" stratigraphic and physical properties data in the $15-\mathrm{km}$-wide undeformed fill of the trench wedge (Fig. 1). Two lithologic units were identified. Unit 1 (0-566 m sub-bottom) consists primarily of Quaternary turbidites and hemipelagic mud deposited in the trench. Unit 2 (566-749.4 m sub-bottom) lacks the coarse silt and sand layers and consists of lower Quaternary to upper Pliocene hemipelagic mudstones, originally deposited in the Shikoku Basin.

Site 583, situated on the first structural step or frontal fault terrace of the trench slope, was to sample the tectonically deformed trench-fill sediments, to penetrate the fault zone, and to continue the sampling of the sediments in the deformed footwall. Eight holes were drilled at Site 583; they will be discussed as two composite sequences representing two significantly different locations: Holes 583B, 583C, 583D (hereafter called 583B,C,D) and

\footnotetext{
${ }^{1}$ Kagami, H., Karig, D. E., Coulbourn, W. T., et al., Init. Repts. DSDP, 87: Washington (U.S. Govt. Printing Office). 14853 .

2 Address: Department of Geological Sciences, Cornell University, Ithaca, New York
}

Holes 583, 583E, 583F, 583G (hereafter called 583,E,F,G). Hole $583 \mathrm{~A}$, which penetrated only $54 \mathrm{~m}$, is not discussed because the physical properties data from this shallow hole duplicate the surficial data from the other two composite holes.

The sediments throughout all the holes at Site 583 can be described as Quaternary hemipelagic muds with sand and silt units, generally resembling Unit 1 of Site 582 . Holes $583, \mathrm{E}, \mathrm{F}, \mathrm{G}$ were drilled on the frontal structural terrace whereas Holes 583B,C,D were drilled $475 \mathrm{~m}$ south-southeast downslope and through the toe of the frontal thrust (Fig. 1). Holes 583B,C,D penetrated a fault splay near $60 \mathrm{~m}$ sub-bottom, as well as the frontal thrust at approximately $170 \mathrm{~m}$ sub-bottom. Holes $583, \mathrm{E}, \mathrm{F}, \mathrm{G}$ were planned to penetrate the frontal fault at about $500 \mathrm{~m}$ sub-bottom, where consolidation and lithification would probably be complete enough for relatively high recovery. We hoped that any changes in physical properties associated with the fault zone would be well developed at these depths. Because of technical difficulties and the intrusion of Typhoon Bess, the fault zone was not penetrated in either Hole $583 \mathrm{~F}$ or Hole 583G. However, Site 583 did sample $450 \mathrm{~m}$ of trench-fill strata that are lithologically similar to Unit 1 of Site 582 , but sampled from a different structural and tectonic setting. These strata provide several interesting comparisons in physical properties between Sites 582 and 583.

\section{METHODS}

A comprehensive program of measurement of physical properties was followed throughout Leg 87 . Special attention was focused on obtaining the maximum quantity of high-quality data from the least disturbed portions of the recovered cores. The parameters measured in the shipboard sampling program were porosity, water content, wetbulk density, shear strength, and compressional-wave and shear-wave 


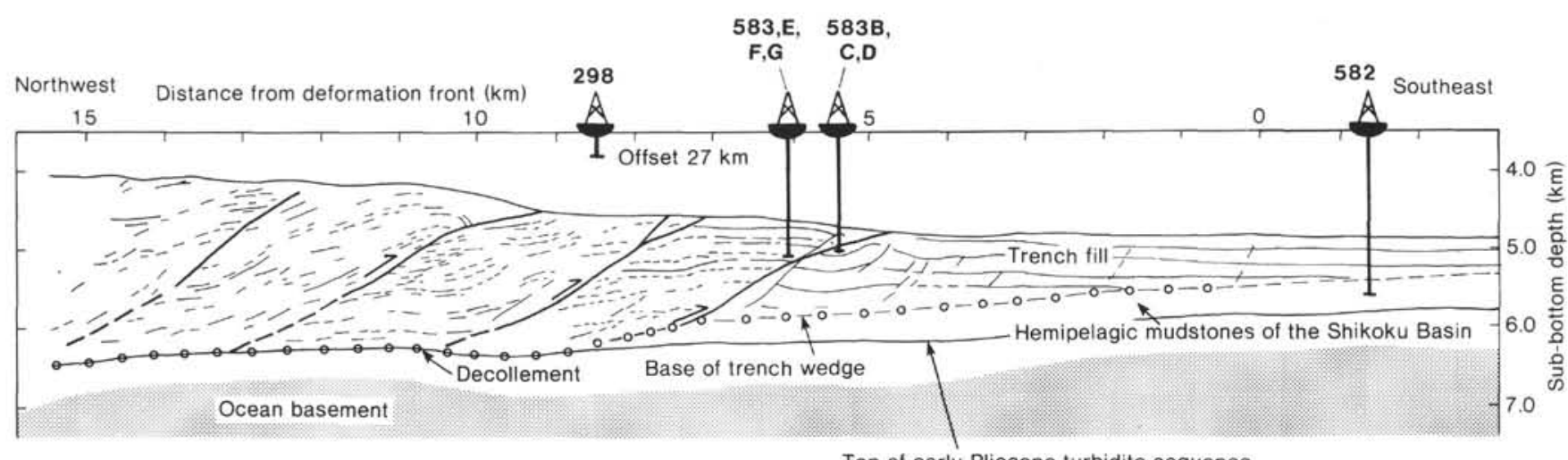

Top of early Pliocene turbidite sequence

Figure 1. Interpretive depth section across the toe of the Nankai accretionary prism from seismic Profile N55-3-1 (Nasu et al., 1982), showing major reflectors, lithologic units, and structural features. Site 582 is located approximately $2 \mathrm{~km}$ seaward of the deformation front in the $15-\mathrm{km}$-wide undeformed trench fill. Site 583, situated on the first structural terrace, is shown here to include two composite sequences: Holes 583B,C,D and Holes 583,E,F,G. Site 298, Leg 31, located $27 \mathrm{~km}$ west-southwest has been projected along strike onto this section to show its position in the prism relative to the Leg 87A sites. The heavy dotted line marks the base of the trench wedge, which is the contact between the overlying Quaternary turbidites and hemipelagic muds deposited in the trench (Unit 1) and the lower Quaternary to upper Pliocene hemipelagic mudstones (Unit 2) originally deposited in the Shikoku Basin. Underlying the hemipelagites is a sequence of lower Pliocene turbidites that was not sampled during Leg 87 . The decollement is marked with small circles.

velocities. Grain densities measured at Cornell University completed the laboratory data set, which is tabulated in the Appendix at the end of this volume. In situ measurements of physical properties include downhole well logs, heat flow, and pore-water pressures. All these data, with the exception of the pore-water pressures, are reported in the site chapters, Sites 582, 583, and 584 (all this volume). The sampling and measurement techniques for shipboard measurement of physical properties are described in the Introduction and Explanatory Notes chapter (this volume). This chapter will review the data from Sites 582 and 583 and will attempt to interpret these data as well as to compare the results with those from Sites 297 and 298 of DSDP Leg 31.

\section{Correlation}

Detailed correlation of physical properties between Sites 582 and 583 is difficult for several reasons. Distinct marker beds are absent, making a lithologic correlation tentative. Biostratigraphic zonation is difficult in both sites because of low core recovery, paucity of fossils in these rapidly deposited sediments, poor preservation, and considerable mixing of the microfauna in these turbiditic sediments. Correlation based on seismic reflection character, supplemented with the most reliable biostratigraphic dates, has been made (Karig, this volume), but lacks the detail necessary for comparisons of physical properties. Slight arcward tectonic thickening and deformation of the trench-fill strata and the large number of holes drilled in slightly different settings at Site 583 add to the difficulty of comparing the physical properties of the two sections.

In the absence of firm stratigraphic correlation, the most reasonable comparison of physical properties might be made by matching the profiles at the sediment/water interfaces because the lithology of Unit 1 in both Sites 582 and 583 is generally uniform, and gravitational forces play a major role in their consolidation history.

In Holes 583B,C,D, steep and constant dips of bedding extending to the surface suggest that the uppermost part of the section has been removed by erosion (Lundberg and Karig, this volume). Interpretation of the seismic profiles near Site 583 also indicates that this composite hole, drilled in the fold at the top of the frontal thrust, was subject to erosion occurring contemporaneously with thrusting (Karig, this volume). Also indicative of erosion are the first occurrences of fissility, which were found at $114 \mathrm{~m}$ sub-bottom in Hole 583D. In Holes $583, \mathrm{E}, \mathrm{F}, \mathrm{G}$ the first identification of fissility is hampered by poor recovery but occurs somewhere between $126 \mathrm{~m}$, where no fissility is evident, and $198 \mathrm{~m}$ sub-bottom where fissility is well developed. Based on these three lines of evidence, the magnitude of this erosion is estimated to be $10-50 \mathrm{~m}$ (site chapter, Site 583 , this volume). Offsetting the 583B,C,D profile $30-50 \mathrm{~m}$ above that of Site 582 may provide the most reliable correlation.

\section{PHYSICAL PROPERTIES}

\section{Water Content, Bulk Density, Porosity, and Grain Density}

Water-content, bulk-density, and porosity profiles reveal similar trends for both Sites 582 and 583 (Figs. 2A, $2 \mathrm{~B}, 2 \mathrm{C}$ ), principally because the grain density throughout the sections is approximately constant. Porosity (volume of voids/volume total sample) is perhaps best suited to studies of dewatering and tectonic deformation because a change in porosity is a measure of the relative pore fluid loss. For this reason, the water content and bulk densities (2-minute GRAPE) measured in the laboratory have been converted to porosities using grain densities measured in pycnometers. The porosities measured in the laboratory are from clay-rich units because the unlithified sandy units are rarely recovered. Moreover, when they are recovered the sands are highly disturbed, difficult to sample, and yield unreliable data.

The scatter in the data (primarily caused by expansion, coring and sampling disturbance, and lithologic variability) is wide at shallow levels. Lithologic variability, predominantly changes in grain-size distribution, produces random scatter about the mean porosity. Gas expansion and coring and sampling distribution tend to skew the porosity profiles toward higher values, but because the magnitude of this shift is not known, the values cited are averages. This scatter lessens with depth as gas concentrations decrease and sample stiffness and lithologic homogeneity increase.

Average porosities in the Site 582 samples decrease steadily from $65 \%$ near the surface to $44 \%$ at $566 \mathrm{~m}$ sub-bottom, which coincides with the contact between the trench-fill turbidites and hemipelagites of Unit 1 and the hemipelagic mudstones of Unit 2. The contact is marked by a decrease in coarse silt and sand accompanied by a gradual increase in porosity to a local maximum of $52 \%$ at $625 \mathrm{~m}$ sub-bottom. Below $625 \mathrm{~m}$ the 
porosity decreases again, as expected from gravitational consolidation, to $47 \%$ at the base of the hole $(749.4 \mathrm{~m})$ (Fig. 2A).

The porosity-depth profiles from each of the sequences drilled at Site 583 in sediments lithologically similar to Unit 1 of Site 582 show gradual porosity decreases from $63 \%$ near the surface to $42 \%$ at $450 \mathrm{~m}$ sub-bottom (Fig. 2B, 2C). The details of the two profiles differ somewhat. The surficial porosity in Holes 583B,C,D decreases rapidly from $63 \%$ at $0 \mathrm{~m}$ to $52 \%$ at $25 \mathrm{~m}$ sub-bottom. At greater depths, the rate of porosity decrease is much lower, with porosity reaching $42 \%$ at $325 \mathrm{~m}$ sub-bottom. In Holes 583,E,F,G the loss of porosity also proceeds more rapidly in the uppermost strata but at a slower rate than in Holes 583B,C,D. Porosity decreases to $47 \%$ at $125 \mathrm{~m}$ sub-bottom. Below $125 \mathrm{~m}$ in Holes 583,E,F,G and $85 \mathrm{~m}$ in 583B,C,D, the two profiles are nearly identical. The relatively lower porosities in the shallowest sediments of Holes 583B,C,D can be attributed to erosion.

During an abbreviated logging program in Hole 583F, four runs were made over the interval between 90 and $250 \mathrm{~m}$ sub-bottom (site chapter, Site 583, this volume). Compensated neutron log (CNL) and compensated formation density (FDC) profiles show that, throughout the logged interval, sand-rich units were more abundant in situ than in the recovered cores and that porosity varies with lithology.

Porosity in the sand-rich units is nearly constant at 28 to $30 \%$ throughout the logged section. The in situ porosities measured in the clay-rich units decrease steadily from $47 \%$ at $90 \mathrm{~m}$ to $38 \%$ at $250 \mathrm{~m}$ sub-bottom. These values are consistently $4-5 \%$ lower than the laboratory values, an expected effect attributed to porosity rebound caused by sampling.

At Site 298, situated $27 \mathrm{~km}$ west-southwest of Site 583 on a slope terrace similar to Site 583 , but about $3 \mathrm{~km}$ further from the deformation front, two lithologic units were identified (Ingle, Karig, et al., 1975b). Unit 1 (0-174.2 $\mathrm{m}$ sub-bottom) is a cobbley clayey silt and silty clay, probably representing slump deposits. Unit 2 (194.2$611 \mathrm{~m}$ sub-bottom) consists of clay, silt, and clayey and silty sand that resemble Unit 1 at Site 582 and its equivalent at Site 583 (site chapter, Site 583, this volume). Few high-quality porosity measurements are available from Site 298 , but the most reliable of these show a gradual decrease from about $46 \%$ at $185 \mathrm{~m}$ sub-bottom to about $34 \%$ near the base of the hole.

The porosity profiles from Sites 582,583 , and 298 are remarkably similar (Fig. 3). Between 0 and $250 \mathrm{~m}$ subbottom, the profiles for Holes 583B,C,D and 583,E,F,G show a slightly higher gradient than the profile for Hole 582 at corresponding depths. At depths greater than $250 \mathrm{~m}$ sub-bottom, the porosities in the sediments of the three holes are nearly identical. Between 185 and $550 \mathrm{~m}$ subbottom, the average porosities in Unit 2 from Site 298 are slightly lower than the porosities from Sites 582 and 583. Below $550 \mathrm{~m}$ sub-bottom, the comparison between Sites 298 and 582 is not warranted because of the change in lithology to hemipelagic mudstones in Site 582 .
The porosity profile for Site 297 located in the northwestern corner of the Shikoku Basin about $100 \mathrm{~km}$ directly south of the Nankai Trough is shown for comparison. The sequence drilled at Site 297 is predominantly olive gray claystone capped with diatom-rich and nannofossil-rich clays. The consistently higher porosities of the sediments at Site 298 relative to those at Site 297 were interpreted to indicate tectonic dewatering (Ingle, Karig, et al., 1975a,b). In retrospect, the lithologic differences between the two sequences drilled at these sites can account for the different porosity profiles.

Several important observations emerge from these porosity profiles. First, the slight differences in porosity between the profiles suggest that a small amount of excessive dewatering has accompanied the deformation and tectonic thickening in the upper $550 \mathrm{~m}$ of sediments in the toe of the Nankai wedge.

Second, porosity increases below the base of the trench wedge at Site 582. This gradual increase is coincident with the transition from distal turbidites deposited in the trench wedge to hemipelagic muds of the Shikoku Basin.

Third, the porosity and formation density logs show that the predominantly clay-rich sediments recovered in the core barrel are not representative of the entire sequence. In fact, unlithified sands, interbedded with the clay-rich units, make up a significant portion of the section. At equivalent depths in the logged section, the sand units have porosities that are lower than the adjacent clay-rich sediments. However, this difference decreases markedly with depth, from $18 \%$ at $90 \mathrm{~m}$ to $8 \%$ at $250 \mathrm{~m}$ sub-bottom. The laboratory porosity profiles indicate the porosity of only the clay-rich portions of Unit 1 in Sites 582 and 583. Because they exclude the sand-and-silt-dominated portions, these values should not be used as representative of the sequence as a whole.

\section{Shear Strength}

Shear strength of sediments was measured on board in the split cores using three standard instruments: Wykeham Farrance Vane Shear, Soiltest CL600 Torvane, and Soiltest CL700 Pocket Penetrometer (see site chapters, Sites 582 and 583 , this volume). These instruments are only useful in the less consolidated uppermost portions of the sediment sections (about $200 \mathrm{~m}$ ), where sampling disturbance produced by gas expansion, drilling, and handling is the most severe. Sampling disturbance is presumably responsible for the tremendous scatter in the data. Because sampling disturbance reduces the shear strength, only the maximum values (those shown in Figs. 2A, 2B, 2C) are considered reliable.

At depths beyond the capacity of the standard shipboard shear-strength instruments, continued increase in shear strength was measured qualitatively (Table 1) by recording: (1) the technique required to extract the water content samples from the split cores (Boyce cylinder, razor blade, or rock saw) and (2) the depth within the section at which visible physical changes were noted (incipient fissility, first drilling biscuits, last drilling biscuits/ first coherent rocks). 


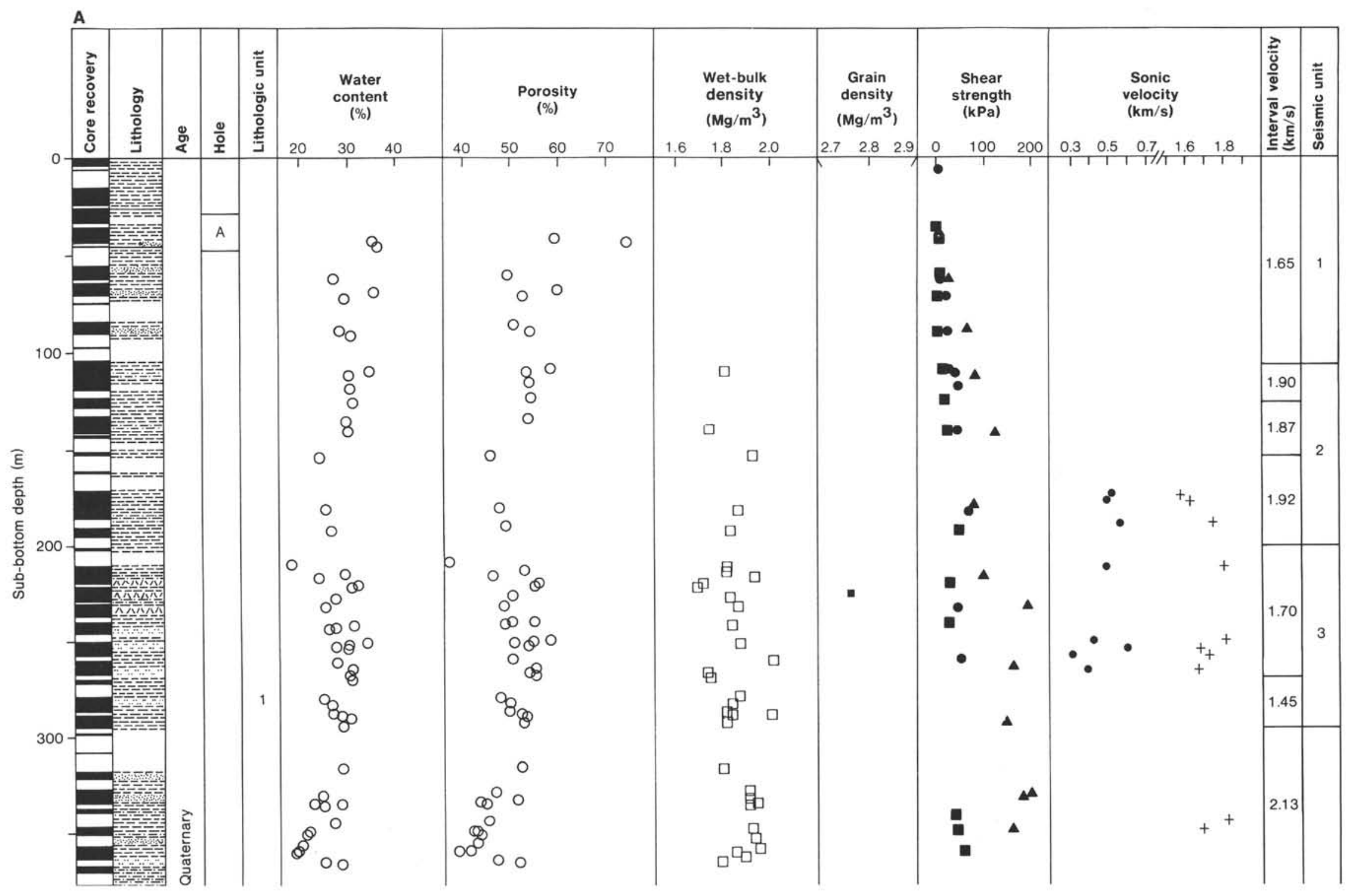




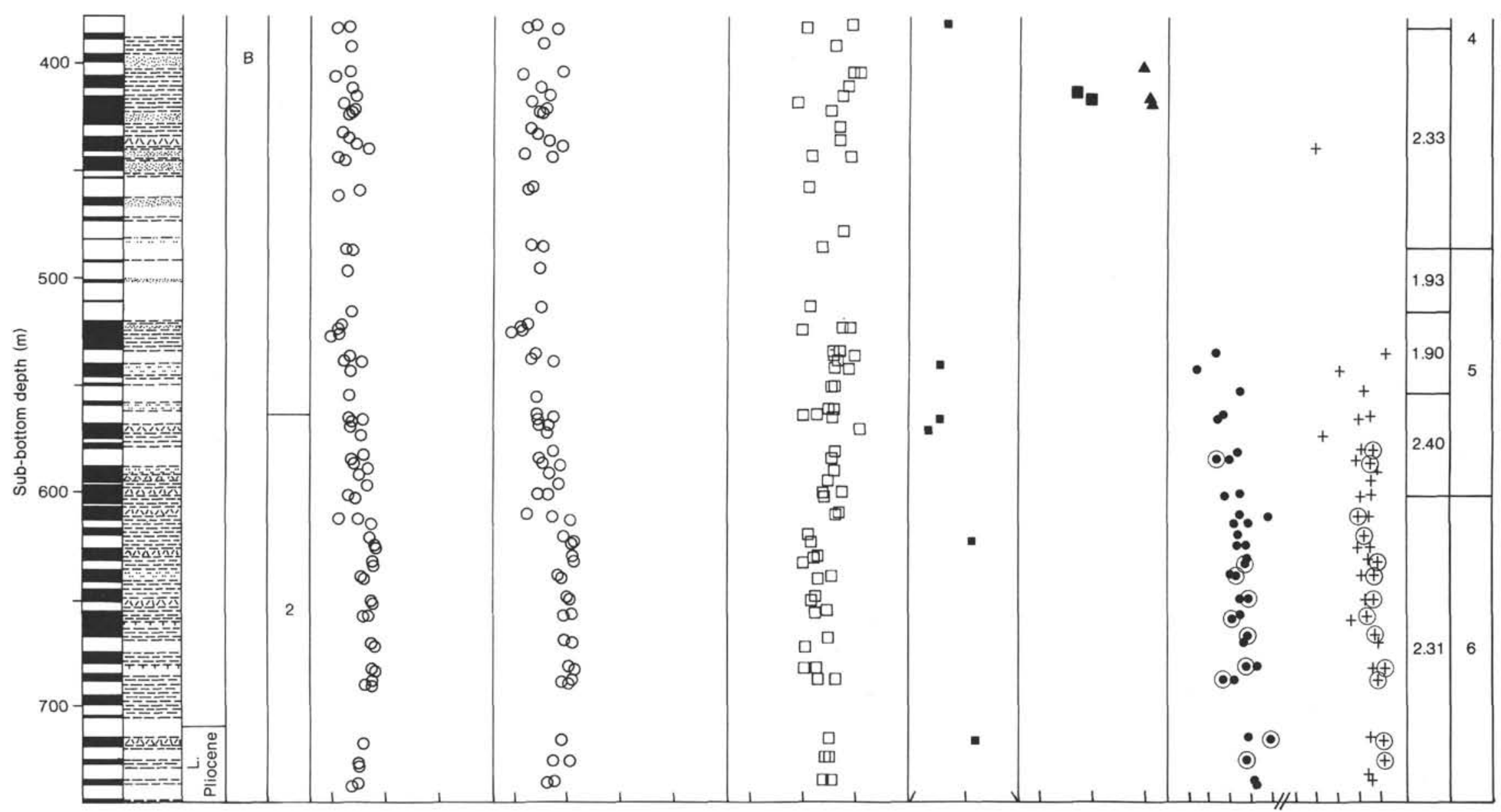

Figure 2. Sub-bottom depth plotted versus physical properties. Water contents, measured gravimetrically, are shown by open circles. Also shown by open circles are porosities, which were calculated from water contents using grain densities measured on shore in pycnometers. Wet-bulk densities (open squares) were calculated from 2-minute GRAPE counts. Shipboard shearstrength/cohesion measurements were made with three devices; vane shear (solid circles), Torvane (solid squares), and pocket penetrometer (solid triangles). Laboratory sonic velocities were measured using the Hamilton Frame and the New Sonic Viewer. The compressional-wave and shear-wave velocities measured parallel to the normal to the axis of the cores are shown by crosses and dots respectively. Measurements taken perpendicular to the normal to the core axis are circled. Interval velocities were calculated from Profile N55-3-1 (Site 582 chapter, this volume). See text for further description of the data. For key to lithologic symbols, see Introduction and Explanatory Notes chapter (this volume). All the data with the exception of the interval velocities are tabulated in the Appendix at the end of this volume. A. Site 582. B. Holes 583B,C,D (see following page). C. Holes 583,E,F,G (see following page) 


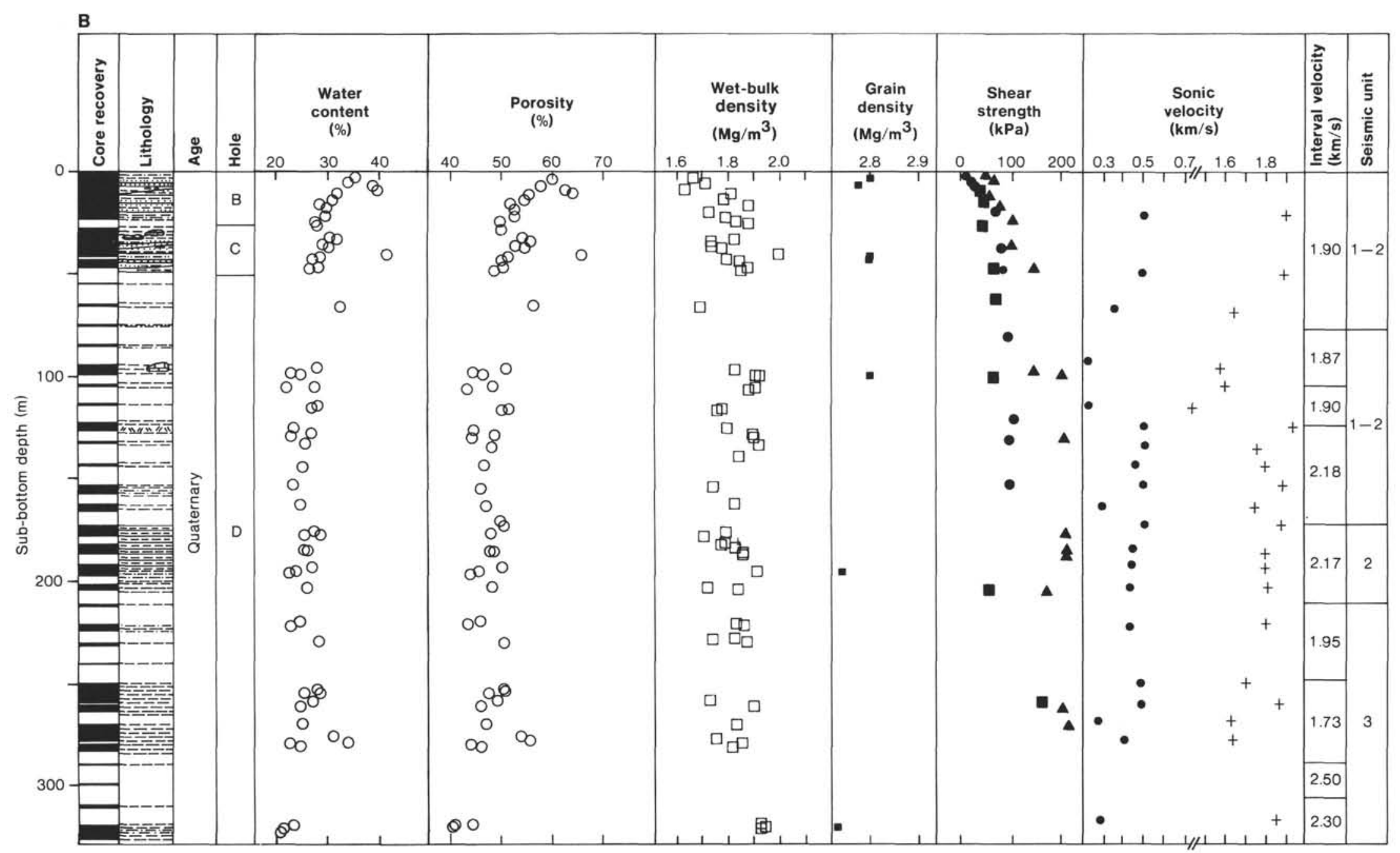




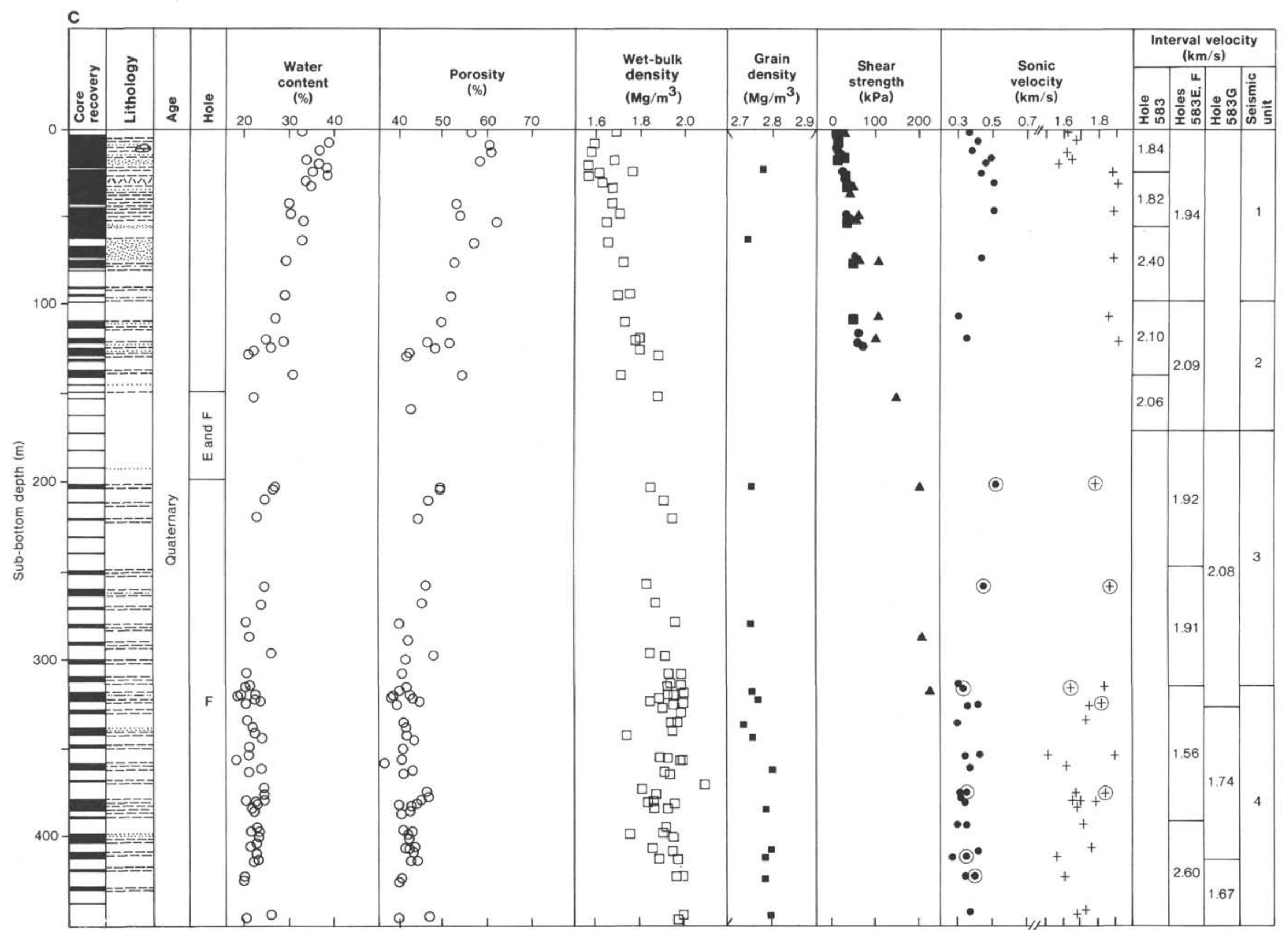




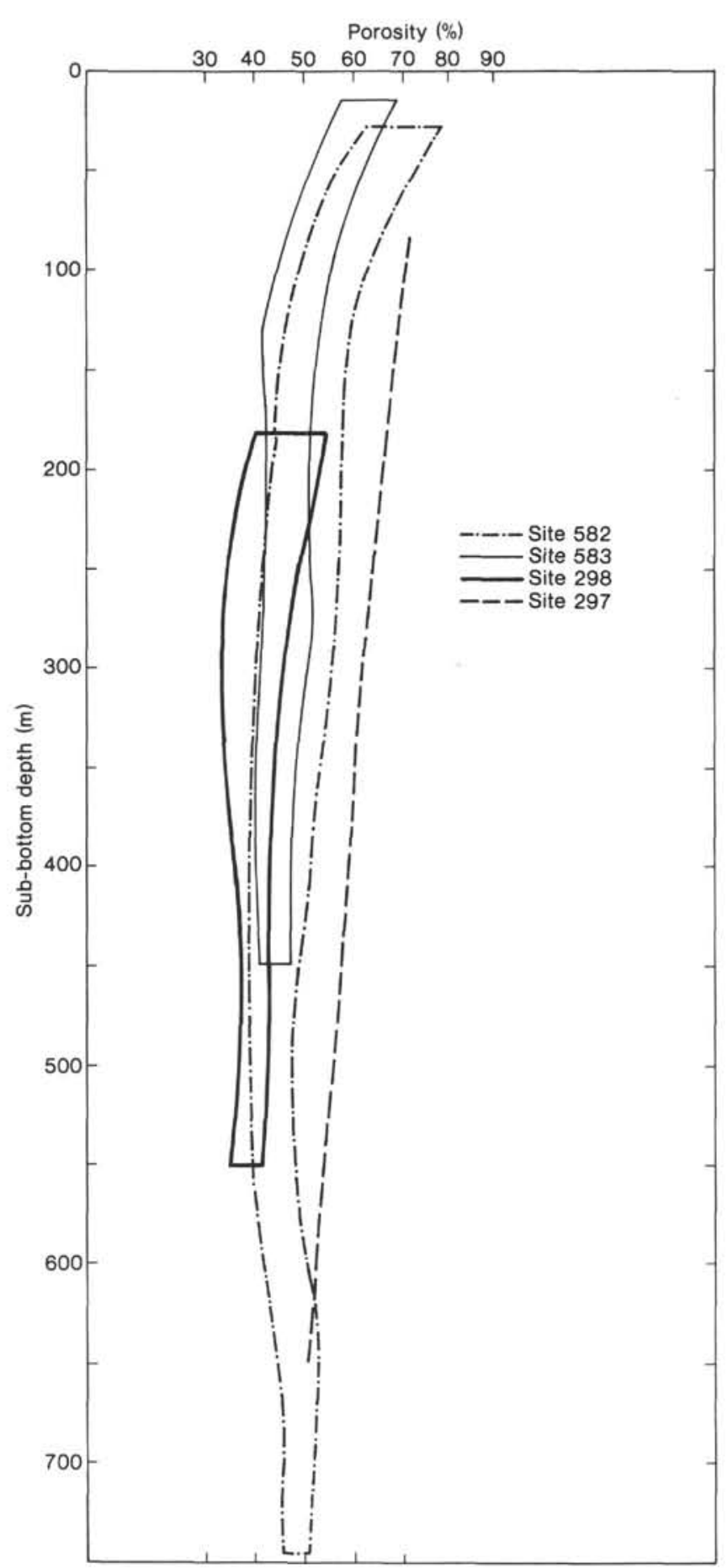

Figure 3. Plot of depth versus porosity, comparing profiles for Sites $582,583,297$, and 298 . The Site 583 curve is a composite of the profiles for Holes 583B,C,D and Holes 583,E, F, G, with the former offset $40 \mathrm{~m}$ below the later. The profile for Site 298 shows porosities of the clay, silt, and clayey and silty sand of Lithologic Unit 2, whereas the profile for Site 297 is measured in predominantly olive gray claystone (Ingle, Karig, et al., 1975a,b).

The gradient of maximum shear-strength-depth profile for Site 582 decreases with depth but, if projected linearly, is $0.60 \mathrm{kPa} / \mathrm{m}$. In the sequence of Holes $583, \mathrm{E}, \mathrm{F}, \mathrm{G}$, the gradient is nearly linear at $1.0 \mathrm{kPa} / \mathrm{m}$. At Holes 583B,C,D, it increases throughout the upper
Table 1. Measure of qualitative shear strength by comparison of subbottom depths (in $\mathrm{m}$ ) to certain sampling techniques and physical changes, Sites 582 and 583.

\begin{tabular}{lcccccccc}
\hline & \multicolumn{3}{c}{ Sampling technique } & & \multicolumn{3}{c}{ Visible physical change } \\
\cline { 2 - 3 } Hole(s) & $\begin{array}{c}\text { Boyce } \\
\text { cylinder }\end{array}$ & $\begin{array}{c}\text { Razor } \\
\text { blade }\end{array}$ & $\begin{array}{c}\text { Rock } \\
\text { saw }\end{array}$ & & $\begin{array}{c}\text { Incipient } \\
\text { fissility }\end{array}$ & $\begin{array}{c}\text { First drilling } \\
\text { biscuits }\end{array}$ & $\begin{array}{c}\text { Unbiscuited/ } \\
\text { coherent rocks }\end{array}$ \\
\hline 582 & $0-542$ & $526-617$ & $586-741$ & & 254 & 300 & 650 \\
$583 B, C, D$ & $0-230$ & $177-322$ & & & 114 & 160 & \\
583,E,F, & $0-319$ & $150-399$ & $320-444$ & & 160 & 195 & \\
\hline
\end{tabular}

Note: Blank indicates that the hole was terminated before this technique was required or be fore this feature was identified.

$50 \mathrm{~m}$, but also averages $1.0 \mathrm{kPa} / \mathrm{m}$ over the uppermost $200 \mathrm{~m}$. The increasing gradient in Holes 583B,C,D can be explained by the erosion of several tens of meters of surficial sediments and subsequent slumping and slope sedimentation.

The qualitative estimates of shear strength are presented in Table 1. At depths where the "sampling technique" zones overlap, one of the two techniques was used depending on the consistency of the individual samples. Each of the qualitative shear-strength measurements cited indicates that at any given depth, the shear strength of the sediments at Site 582 is lower than at Site 583 . Qualitatively, the shear strength of sediments in Holes 583B,C,D is slightly greater than in the companion Holes $583, \mathrm{E}, \mathrm{F}, \mathrm{G}$. Again, this may be explained by a greater maximum past-burial depth for the sequence at Holes 583B,C,D.

In summary, the shear-strength gradient, as measured both quantitatively and qualitatively, is greater throughout the entire sequence at Site 583 than at Site 582 . Below $350 \mathrm{~m}$ sub-bottom at both Sites 582 and 583, the qualitative shear strength increases rapidly whereas water loss is minimal. Collectively, these results suggest that shear strength must be a complex function of numerous parameters in addition to lithology and water content.

\section{Sonic Velocities}

Laboratory measurement of compressional-wave velocities, $V_{p}$, and shear-wave velocities, $V_{s}$, was hampered by high acoustic attenuation caused by gas expansion and drilling disturbance. Velocities are reported for each sample through which sonic waves could be transmitted and received. The quality of sonic velocities measured in the laboratory varies inversely with the degree of sample disturbance and, in general, improves with depth as sample disturbance and acoustic attenuation decrease. Downhole sonic velocity logs, which are useful for verifying laboratory data, were planned for both Sites 582 and 583 but were run only in a short interval of Hole 583F.

At Site 582, few laboratory sonic velocity measurements were possible in the upper $500 \mathrm{~m}$ of the section because of the high acoustic attenuation caused by numerous extension cracks in these gassy sediments. From the first reliable velocity of $1.59 \mathrm{~km} / \mathrm{s}$ at $175 \mathrm{~m}$, compressional velocity increases nearly linearly to $1.93 \mathrm{~km} / \mathrm{s}$ at $730 \mathrm{~m}$ sub-bottom (Fig. 2A).

The correlation of seismic profiles and cored lithologies led to the division of the Site 582 sequence into six seismic units (site chapter, Site 582, this volume). Inter- 
val velocities calculated for each of these units generally increase downhole but show some local velocity inversions not seen in the laboratory velocities. It is possible that some of these apparent downhole decreases in velocity may be artifacts of the calculations and of differences in correlation rather than representing true property inversions. In all but seismic Unit 3, the interval velocities, which estimate average in situ values, are higher than those measured in the laboratory.

Shear-wave velocities in the zone from 175 to $275 \mathrm{~m}$ sub-bottom at Site 582 are rather scattered but average approximately $0.5 \mathrm{~km} / \mathrm{s}$. Acoustic attenuation was too great to obtain shear-wave velocities in the intermediate levels of the section, but velocities of about $0.45 \mathrm{~km} / \mathrm{s}$ were obtained at $525 \mathrm{~m}$ sub-bottom. Below this depth, $V_{s}$ increased nearly linearly to $0.65 \mathrm{~km} / \mathrm{s}$ at the base of the hole $(749.4 \mathrm{~m})$, where velocities were measured parallel as well as perpendicular to the normal to the core axis. No consistent pattern is seen between the parallel and perpendicular values for either the shear or compressional velocities. The shear-wave velocities measured in the uppermost sediments are slightly higher than expected when compared to previously published data (Hamilton, 1976b). As a group, however, the shear-wave velocities throughout the section agree with values for water-saturated silt-clays and turbidites (Hamilton, 1976b).

At Site 583, the most striking observation from the laboratory $V_{s}$ and $V_{p}$ data is that they show considerable scatter and do not simply increase with depth. In Holes 583B,C,D, near-surface velocities are relatively high with $V_{s}$ and $V_{p}$ values of 0.5 and $1.9 \mathrm{~km} / \mathrm{s}$, respectively. This again may indicate the deeper burial before erosion. Relatively low velocities, with $V_{s}$ as low as $0.23 \mathrm{~km} / \mathrm{s}$ and a minimum $V_{p}$ of $1.58 \mathrm{~km} / \mathrm{s}$ measured between 50 and $115 \mathrm{~m}$ sub-bottom, may be a result of disturbance of these soft sediments in the region bounding the fault splay at about $70 \mathrm{~m}$. Another low-velocity zone in Holes $583 \mathrm{~B}, \mathrm{C}, \mathrm{D}$, between $250 \mathrm{~m}$ and the base of the hole $(325 \mathrm{~m}$ sub-bottom), is more difficult to explain.

In the upper $25 \mathrm{~m}$ of Holes 583,E, F, G, laboratory $V_{p}$ remains nearly constant at about $1.62 \mathrm{~km} / \mathrm{s}$, whereas $V_{s}$ increases from 0.35 to $0.50 \mathrm{~km} / \mathrm{s}$. Between 25 and $300 \mathrm{~m}$ sub-bottom few velocity measurements were taken because of poor core recovery. The few available data show that at $25 \mathrm{~m}$ sub-bottom $V_{p}$ increases abruptly to $1.90 \mathrm{~km} / \mathrm{s}$ and remains nearly constant to $300 \mathrm{~m}$ subbottom. Over this same interval, the shear-wave velocities are not reliable, presumably because of the highly disturbed nature of the sediments. At depths greater than $300 \mathrm{~m}$, both $V_{s}$ and $V_{p}$ show wide scatter and decrease slightly with depth to the base of the hole at about $440 \mathrm{~m}$ sub-bottom. This low-velocity zone between $300 \mathrm{~m}$ subbottom in Holes 583,E,F,G correlates stratigraphically with that found below $250 \mathrm{~m}$ in Holes 583B, C, D, if (as previously suggested) approximately $40 \mathrm{~m}$ of surficial sediments have been eroded from Holes 583B,C,D. In each of these holes the decrease in velocity corresponds to the first occurrence of Chondrites and other fossil traces.

Through all depths in Holes 583B,C,D the interval velocities determined from Profile N55-3-1 (site chapter,
Site 583, this volume) are higher than the laboratory velocities, but the difference between them is variable (Fig. 2B). The interval velocity of sequentially deeper units increases, except between 210 and $295 \mathrm{~m}$ sub-bottom in seismic Unit 3, where the velocity gradient reverses. The estimated depth of this low-velocity zone is approximately $30-40 \mathrm{~m}$ higher in the section than the similar zone revealed in the laboratory data. Nevertheless, these two data sets are probably identifying the same zone because the process of correlating seismic profiles with cored lithology, which is used to delineate these intervals, is imprecise, particularly in these holes with very low core recovery.

The interval velocities calculated for the 583,E,F,G section (site chapter, Site 583, this volume) are again higher than the laboratory values by varying amounts. The fluctuations in interval velocities with depth are remarkably similar to those of laboratory data. Moreover, the low-velocity zone again correlates with the zone of chondritic and burrowed sediment.

In situ velocities were measured during the logging program in Hole $583 \mathrm{~F}$ over the interval between 90 and $260 \mathrm{~m}$ sub-bottom (site chapter, Site 583 , this volume). When interpreted together, the sonic and formation-density logs showed that at a given depth the sand-rich units have significantly higher velocities than the clay-rich units, which were preferentially recovered from the drill holes. These logs (Figs. 37 and 38, site chapter, Site 583, this volume) indicate that between 100 and $226 \mathrm{~m}$ sub-bottom $V_{p}$ of the clay-rich sediments increases linearly from 1.72 to $1.88 \mathrm{~km} / \mathrm{s}$, whereas $V_{p}$ of the sand-rich strata remains constant near $2.00 \mathrm{~km} / \mathrm{s}$.

The interval logged was one of very poor recovery, perhaps because of the high percentage of interbedded sand, and therefore provided few laboratory velocities. The laboratory values are clearly most similar to the clay-rich values, as expected from the lithologic similarity (Fig. 2C). In contrast, the similarity of the interval velocities over the logged interval to the velocities logged in the sand-rich units (averaging $2.00 \mathrm{~km} / \mathrm{s}$ ) also suggests a high sand content for this section (Fig. 2C).

The velocity logging program again showed that the cores provide a misleading impression of a clay-rich stratigraphy when, in fact, silts and sands are equally abundant. The presence of sand and silt within the section raises the bulk compressional velocity above that shown in the laboratory velocity profile.

The velocities measured in the clay-rich lab samples are very similar to the in situ velocities of the clay-rich units. This correspondence suggests that the velocities of cohesive sediments are not strongly pressure dependent at depths of up to $\sim 250 \mathrm{~m}$ sub-bottom.

\section{Pore-Water Pressures}

Pore-water pressures play a critical role in determining the effective stress state in sedimentary deposits. The effective stress determines the degree or state of consolidation, which plays a major role in determining the ultimate strength of the unit, particularly in young shallow sediments not affected by diagenesis. In recent years much attention has been focused on pore-water pressures and 
their role in controlling the mechanics of deformation in accretionary prisms (e.g., Davis et al., 1983; Dahlen et al., 1984). Drilling in the Nankai Trough offered an opportunity to measure in situ pore-water pressures rather than infer them from the mechanical behavior as has often been done in the past.

At Site 583, a combined piezometer probe and porewater sampler was employed at various intervals whenever hole stability conditions permitted. Unfortunately, it appears that for most attempts the probe was inserted into cuttings that collected in the hole during cessation of circulation rather than into undisturbed sediments. In addition, during none of these runs was the probe allowed to remain below the mudline long enough after the closure of the pore-water sampling device to allow the pore-water pressures to stabilize at ambient levels. As a result, the final recorded pore pressures were 259 to $1379 \mathrm{kPa}$ below the pressure recorded just above the mudline. The steep negative pore-pressure gradient that these values imply is of nongeologic origin.

\section{DISCUSSION AND CONCLUSIONS}

\section{Effect of Lithology on Physical Properties}

Two important parameters other than effective stress that affect the variation of physical properties with depth are sediment composition and grain size. The effect of compositional and grain-size variation on porosity and sonic velocity can be seen in both the laboratory and in situ data.

The result of lithologic variation on porosity measured in the laboratory is graphically illustrated in the porosity profile of Site 582 (Fig. 2), where at a depth of $566 \mathrm{~m}$ sub-bottom, coincident with the contact between Unit 1 and the Shikoku Basin hemipelagics of Unit 2, the porosity increases significantly. This increase in porosity with change in lithology is not surprising because equilibrium porosity for ambient pressure will vary depending on the composition and grain size of the sediment (Mitchell, 1976). Bulk sample X-ray diffraction showed the principal compositional change between Unit 1 and Unit 2 is the complete disappearance of swelling clays below a depth of $566 \mathrm{~m}$ sub-bottom (site chapter, Site 582, this volume). Complete grain-size analyses are not available, but smear-slide estimates indicate that in the clay-rich units, which were used for porosity measurements, the sand and silt content are lower in Unit 2 than in Unit 1 . The change in clay mineral content and decreasing average grain size probably account for part of the porosity increase in Unit 2, but low permeabilities and the absence of sand and silt layers may also be important.

Permeability data are not available for this sequence, but lower values would be anticipated for this relatively homogeneous, finer-grained unit than for the interbedded sands and silty clays of Unit 1 . Clay-rich samples of equal porosity from Units 1 and 2 would be expected to have similar permeabilities. However, the clay-rich portions of Unit 1 may consolidate and dewater faster in situ than portions of Unit 2 if the more permeable interbedded sands and silts aid in water removal. In this situ- ation the effective permeability of a clay-rich unit that is bounded by coarser-grained units is increased. The gradual increase in porosity of Unit 2 between 566 and $625 \mathrm{~m}$ sub-bottom may occur because the basal sand layers of Unit 1 accelerate the dewatering locally, but this ability to increase dewatering diminishes with distance from the lithologic contact. At depths below $625 \mathrm{~m}$ sub-bottom, relatively high porosities may be maintained as water migration is inhibited.

Permeabilities may also play a role in determining porosity distributions by controlling pore-water pressures and effective stress conditions. Rapid loading of the Shikoku Basin hemipelagics, produced by high accumulation rates $(>500 \mathrm{~m} / \mathrm{Ma})$ of the overlying trench fill, could generate pore-water pressures greater than the hydrostatic pressures. With several hundred meters of superincumbent trench-fill sediments, low permeabilities could inhibit water outflow and cause high pore-water pressures, low effective stresses, and abnormally high porosities to persist in the hemipelagites.

The logging program run in Hole $583 \mathrm{~F}$, despite its brevity, was also useful for studying the effect of lithology on physical properties. Principally, the logs document the extreme bias of the coring operation toward recovery of clay-rich strata and provide physical properties of the noncohesive sand-rich units that were not recovered.

In the upper portion of the logged sequence (80-150 m sub-bottom), which was drilled by the hydraulic piston corer, core recovery was $32 \%(22.5 \mathrm{~m})$ of which $25 \%$ $(6 \mathrm{~m})$ was rich in sand and silt, whereas the remaining $75 \%(16.5 \mathrm{~m})$ was rich in clay. The remainder of the section (150-250 m sub-bottom) was rotary drilled and retrieved $5.5 \%(5.5 \mathrm{~m})$ of the total sequence, of which $15 \%(0.8 \mathrm{~m})$ was predominantly rich in sand and silt and $85 \%(4.7 \mathrm{~m})$ rich in clay. In marked contrast, interpretive estimates from the logs indicate a $60 \%$ clay-rich/ $40 \%$ sand-rich and silt-rich sequence between 80 and $150 \mathrm{~m}$ sub-bottom, and a $40 \%$ clay-rich $/ 60 \%$ sand-rich and silt-rich sequence between 150 and $250 \mathrm{~m}$ sub-bottom.

Using these logging estimates as a reference, we can categorize the core recovery by lithology to illustrate the preferential recovery of cohesive clay-rich units compared to unlithified sands and silts. Throughout this turbiditic unit the hydraulic piston corer retrieved approximately $20 \%$ of the sand-rich and silt-rich units and $40 \%$ of the clay-rich strata, whereas the rotary drill recovered approximately 2 and $10 \%$, respectively.

The logging data also indicate that these sand-rich and silt-rich units have significantly lower porosity and higher sonic velocity that the adjacent clay-rich layers at a given depth. This observation was missed in the sample data because of the lack of undisturbed sand.

In addition to altering the porosity profile, anomalously high porosities and low effective stresses in the Shikoku Basin hemipelagites may control the position of the decollement by producing a layer that is weak relatively to the overlying trench fill. Weakening of the layer could occur in two ways. First, the higher porosity of the hemipelagites is accompanied by lower cohesive 
strength, which will cause the layer to fail by shear at a lower differential stress than the trench fill, when both layers are confined by the same mean stress. Second, increasing pore-water pressure reduces both the maximum and the minimum principal effective stress but does not reduce the applied differential stress, which induces failure. This idea of a relatively weak layer below the trench fill is supported by seismic reflection images that are interpreted to show the decollement initiating along or near the upper contact of the hemipelagic sequence in the toe of the Nankai prism (Karig, this volume, and Fig. 1).

The physical properties measured from cores are not representative of the porosities of the trench-fill sediments as a whole because they are very strongly biased toward the predominantly clay-rich units that are recovered. To make estimates of bulk physical properties, it is important to know the percentages of sands and clays (or sandstones and mudstone/shale) actually present in the sequence. Based on the logs in Hole 583F, the sequence between 90 and $260 \mathrm{~m}$ sub-bottom is estimated to consist of $50 \%$ sand-rich and $50 \%$ clay-rich units. Thus, estimates of bulk physical properties can be made by averaging the physical properties profiles of the sandrich units with those of the clay-rich strata.

\section{Empirical Correlations}

Empirical relationships between physical properties allow us to extrapolate data to greater sub-bottom depths and also to determine average bulk density from sonic velocity. Several empirical relationships between compressional-wave velocity and bulk density have been developed from different data sets and for diverse purposes. The general velocity-density relationship for sedimentary, metamorphic, and igneous rocks of Nafe and Drake (1957) is insensitive at low densities where no distinction is made between sediment types. More recently, Gardner and others (1974) presented empirical correlations of in situ formation velocity and density for shales, sandstones, and limestones. Hamilton (1978) selected laboratory and in situ data for empirical sonic-velocity-density relationships in various sediments and finegrained sedimentary rock types. Laboratory data used in his correlations are corrected to in situ values using methods discussed by Hamilton (1971). The relationships discussed by Gardner and others (1974) and Hamilton (1978) provide useful comparisons with the Nankai data. The strength of Hamilton's work is that it provides continuous correlations from soft sediments through mudstones and shales. The study of Gardner and others is particularly useful because it includes correlations for sandstones as well as shales.

Compressional-wave velocity and wet-bulk density relationships can be generated for the Nankai data by plotting sonic velocity versus bulk density for the data measured in situ in the drill holes of the Nankai Trough. Laboratory compressional-wave velocity plotted versus laboratory wet-bulk density measured in the sediments of Sites 582 and 583 agree well with the regression curve for soft marine sediments (silty clays and turbidites) of Hamilton (1978) (Fig. 4). The data from Site 582 show

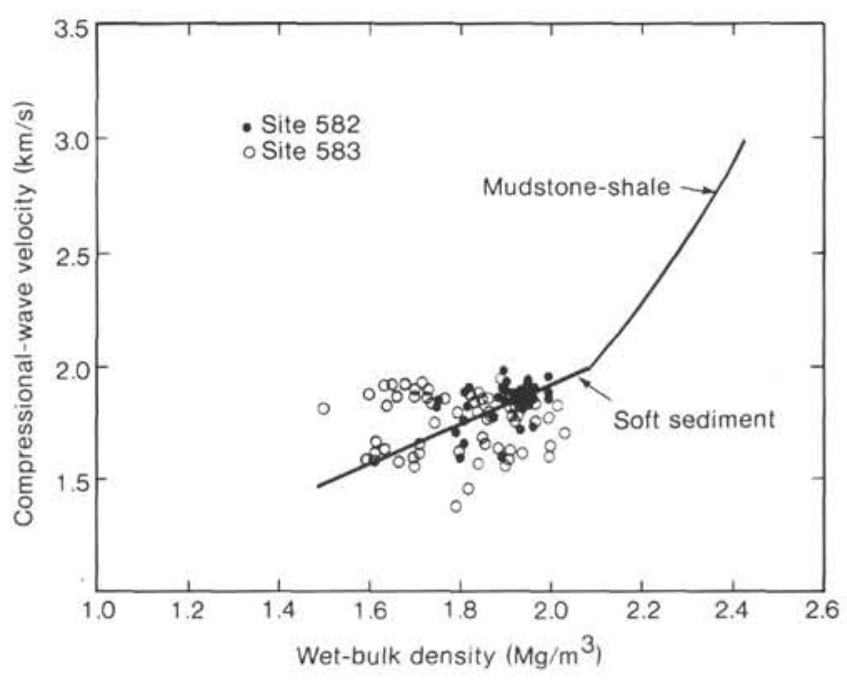

Figure 4. Laboratory compressional-wave velocity plotted versus wetbulk density for Sites 582 and 583. The regression line of Hamilton (1978) for soft marine sediments composed of silt, clays, and turbidites, corrected to in situ conditions, is shown for comparison.

some scatter, which is roughly symmetric about the regression line, but the maximum concentration falls directly on the regression line. This strong concentration reflects the very low density-depth gradient of the sediments at depths below $300 \mathrm{~m}$ at Site 582 .

The relationship between $V_{p}$ and bulk densities from Site 583 shows a wide scatter. Sonic velocity varies from about 1.55 to $1.95 \mathrm{~km} / \mathrm{s}$ at any given bulk density, whereas density ranges from 1.6 to $2.0 \mathrm{Mg} / \mathrm{m}^{3}$ for each velocity. This variation in acoustic wave transmission with density may be a result of minor lithologic differences as well as tectonically disrupted clay fabrics and structures.

The laboratory data from both sites, which has not been corrected for rebound, is surprisingly similar to Hamilton's regression line, which has been converted to the in situ condition. It seems likely that the similarity between these two dissimilar data sets may result from scatter in the data that obscures the effects of rebound on the measured values.

Several points representing compressional-wave velocity and wet-bulk density logged in Hole 583F for end members of clay and sand are plotted in Figure 5. The velocity-density relationship defined by the logging data from the clay-rich units parallels, but lies slightly below Hamilton's (1978) soft-sediment regression line. This offset is expected if the clay-rich units in Hole $583 \mathrm{~F}$ have a finer grain size than those used in Hamilton's correlation.

The points representing clayey units plot among the laboratory data from Site 583 but tend toward higherthan-average densities at a given velocity. The indication is that sample rebound, caused by the removal of in situ stress, reduces the bulk densities of the laboratory samples significantly, but has less effect on the sonic velocities measured in the Hamilton Frame.

The mudstone-shale regression line of Hamilton (1978) and the correlation for shale of Gardner and others (1974) are included in Figure 5 to show trends anticipated at 


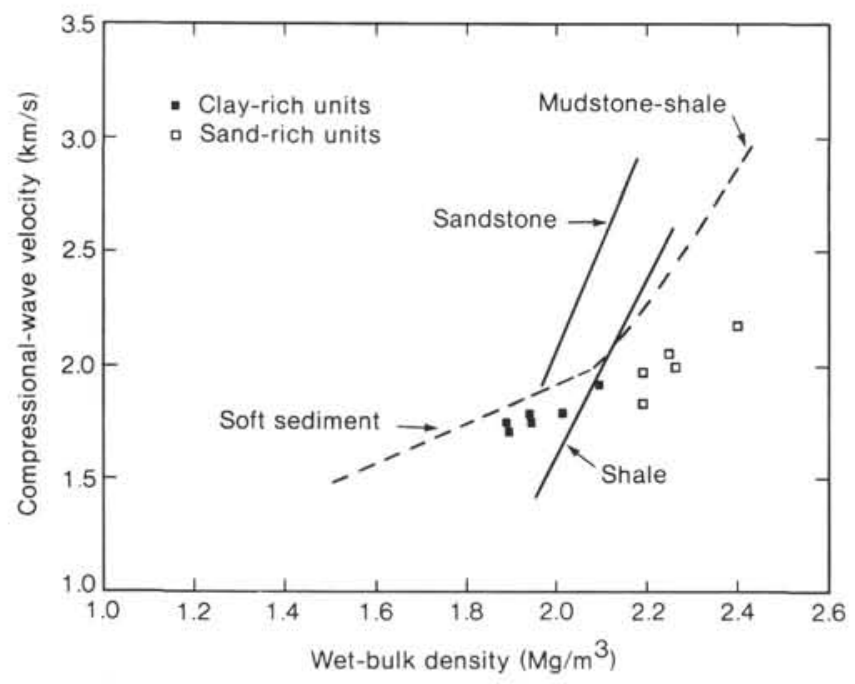

Figure 5. Compressional-wave velocity plotted versus wet-bulk density from sonic and formation density logs in Hole 583F for end members of clay and sand. Hamilton's (1978) soft sediment and mudstone and shale regression lines (dashed lines) are shown as well as correlations for sandstones and mudstones and shales (solid line) (Gardner et al., 1974).

greater depths and for comparison with the empirical relationship for sandstones (Gardner et al., 1974). At densities less than $2.1 \mathrm{Mg} / \mathrm{m}^{3}$, the shale curve of Gardner and others predicts velocities that are much lower than those measured in the Nankai prism or predicted by Hamilton's correlations. This discrepancy suggests that the curve of Gardner and others was incorrectly extrapolated to low bulk densities.

The sandy units identified and measured in the logs show both higher velocities and densities than the adjacent clay-rich units over the logged interval (Fig. 5). Comparison of the data sets for the sand and clay end members is difficult because the ranges of density and velocity for the two groups do not overlap within the short logging interval ( 90 to $250 \mathrm{~m}$ sub-bottom).

Again, a large discrepancy is seen between our data logged in sandy units and Gardner's correlation for sandstones. Gardner's velocity-density correlation predicts much higher velocities than were logged in the sand units of Hole $583 \mathrm{~F}$ over a range of densities of 2.2 to $2.4 \mathrm{Mg}$ / $\mathrm{m}^{3}$. Part of this large discrepancy can be attributed to the unlithified state of the sands in Hole 583F, but this does not adequately explain the entire discrepancy.

\section{Relationship between Shear Strength and Porosity}

Shear strength, as measured by the shipboard equipment, is a measure of resistance to deformation under zero normal stress and is equivalent to a quantity termed cohesion in the Mohr-Coulomb failure criterion. At shallow depths, in less consolidated sediments, shear strength increases markedly with depth and appears to be primarily a function of porosity or water content of the strata. In more deeply buried sediments, some other physical or chemical processes may also increase the shear strength of the dewatering sediments. Two sets of observations from the Nankai region support these ideas.
The first set of observations comes from an investigation of shear strength or cohesion as a function of sub-bottom depth (Figs. 2A, 2B, 2C; Table 1). The sediments of Site 583 show a higher shear-strength-depth gradient than those of Site 582 down to about $250 \mathrm{~m}$ sub-bottom, where the shear strengths in each of the holes approach $200 \mathrm{kPa}$. In each of the holes below approximately $300 \mathrm{~m}$ sub-bottom, qualitative shear strength continues to increase significantly but decreases in porosity are modest.

Shear strength plotted as a function of porosity yields the second set of observation (Fig. 6). Within the scatter of these averaged data, the shear-strength-porosity relationships for Hole 582 and Holes 583,E,F,G are very similar. In Holes 583B,C,D, samples with porosities of 64 to $52 \%$ are more cohesive than samples of the same porosity in either of the other two holes. This zone of relatively high cohesion, which occurs between 0 and $50 \mathrm{~m}$ sub-bottom, again lends support to the idea of erosion at Holes 583B,C,D. It also suggests that the surficial sediments have retained the additional strength gained during prior burial.

Perhaps the most significant observation from the shear-strength-porosity relationship is that the slope of each curve decreases with porosity at a continually decreasing rate. At high porosities and shallow sub-bottom depths, relatively large decreases in porosity accompany the strengthening of the sediments. With increasing sub-bottom depth, smaller porosity reductions are required to produce a given incremental increase in strength.

Several conclusions can be drawn from these observations regarding shear strength as a function of depth and porosity. First, the consistent shear-strength-porosity relationship in the cored sediments of Holes 582; 583B,C,D; and 583,E,F,G suggest that at shallow depths shear strength is primarily controlled by the porosity of the sediments. The slightly higher shear-strength gradients in the sediments of Site 583, as compared to the gradient at Site 582, accompany the accelerated decrease in porosity of the shallowest $200 \mathrm{~m}$ of sediments in the holes at Site 583.

Second, downhole, where the slope of the porosityshear strength curves approaches zero, the sediments may

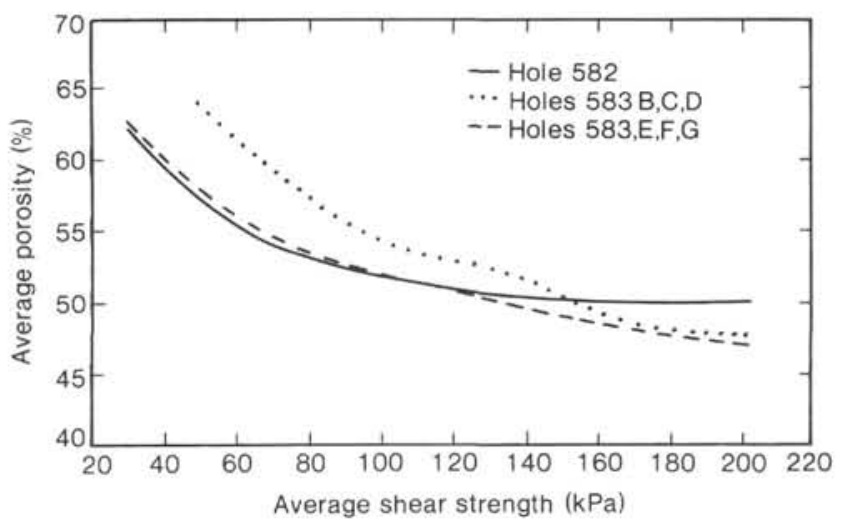

Figure 6. Average porosity plotted versus average maximum shear strength (cohesion) for Holes 582, 583B,C,D, and 583,E,F,G. 
be affected by chemical or mechanical processes other than loss of water that contribute to the continual increase in shear strength. In the deeper portions of the drilled section where porosity decreases very slowly, qualitative shear strength increases markedly, corroborating this conclusion. At this time this conclusion is speculative because the nature of the processes and the depths or stress conditions at which they operate have not been positively documented.

Throughout the drilled sections there is no evidence of precipitation of calcium carbonate or other cementing agents that could increase the cohesion of the sediments. Potassium fixation or other alterations of the crystal structure of the clay minerals could result in increasing shear strength with minimal loss in porosity (Mitchell, 1976). However, six X-ray diffraction patterns for six samples in Hole 582B between 295 and $526 \mathrm{~m}$ subbottom detected no changes in clay mineral abundances or changes in crystal structure (Bray, unpublished data).

Pressure solution or another analogous process that would increase the strength of grain-to-grain bonds is a tempting explanation, but it has not been documented in these relatively shallow sections of the Nankai accretionary prism. Crystallization of new mineral phases such as illite has been documented in individual fracture zones and pseudo-veins within these drilled sequences (R. Knipe, pers. comm., 1984). Further study is required to determine the range of physical and chemical conditions under which this process is operative.

\section{Tectonic Dewatering and State of Consolidation}

The idea of "tectonic dewatering" has received a great deal of attention in recent years. The term describes the phenomenon of dewatering that is accelerated by tectonic shear stresses. In accretionary prisms, tectonic dewatering implies anomalously rapid dewatering as a result of subduction-related stresses. Tectonic dewatering has been reported in several trench wedges (e.g., Nankai Trough, Ingle, Karig, et al., 1975b; Washington continental margin, Carson, 1977; Barbados Ridge complex, Moore and Biju-Duval, 1984).

Evidence leading to the hypothesis of tectonic dewatering in the sediments of convergent margins include: (1) porosity profiles that show anomalously high porosity-depth gradients (e.g., Carson et al., 1974; Bouma and Moore, 1975; Shephard et al., 1981; Marlow et al., 1984 ) and (2) consolidation tests that indicate a state of overconsolidation in sediment sections where evidence argues against deeper past burial depths (e.g., Lee et al., 1973; Trabant et al., 1975; Shephard et al., 1981; Shephard and Bryant, 1983). With the extensive set of physical properties data collected on Leg 87A, we can reevaluate and discuss the state of consolidation and dewatering in the sediments of the Nankai Trough.

\section{Porosity Profiles}

The Leg 87A porosity-depth profiles show that surficial porosity gradients are slightly higher at Site 583 than at Site 582 but that with increasing depth this difference is minimized. When these profiles are considered together with the Hole 298 profile, it appears that to depths of $550 \mathrm{~m}$ sub-bottom, only a small amount of anomalous dewatering had accompanied the deformation and tectonic thickening at Sites 298 and 583.

The similarity between the porosity profiles of lithologically similar trench-fill sequences at Sites 298,582 , and 583 suggests that there is little difference in consolidation state across the toe of the trench wedge as a function of depth. Moreover, because there is no evidence that the sequence at Site 582 had been previously buried to greater depths or subjected to tectonic stresses, it is unlikely that this sequence is overconsolidated. Thus, the state of consolidation for each of these three sequences is apparently one of normal consolidation to underconsolidation.

A comparison of the profiles from the Nankai Trough (Fig. 3) with the porosity profile of Hamilton (1976a, Fig. 4) for terrigenous sediments shows slightly higher gradients in the uppermost $400 \mathrm{~m}$ of sediments in the Nankai sequence. The difference in gradients may be due partially to the high percentage of sand and silt in the sequence, which expedites water removal and lowers the average porosity at a given depth, rather than differences in the state of consolidation. Regardless of the cause, the lower porosities argue against a state of underconsolidation in the Nankai sections.

On the basis of the porosity profiles and the preceding arguments, the sequences in the toe of the Nankai trench wedge are most likely in a state of nearly normal consolidation.

\section{Consolidation Tests}

Consolidation tests performed on drilled cores from Site 582 (Johns, this volume) are interpreted to indicate that the near-surface sample ( $8.90 \mathrm{~m}$ sub-bottom) is overconsolidated, whereas three deeper samples $(72.34,119.79$, and $183.35 \mathrm{~m}$ sub-bottom) are underconsolidated. Nearsurface samples often show an apparent state of overconsolidation because of interparticle cohesion at the time of deposition that is greater than would be produced by the overburden (Johns, this volume; Shephard et al., 1981). Explanation of the inferred state of underconsolidation is less straight forward. The measured permeabilities and average sediment accumulation rates are not of appropriate magnitude to cause the excess pore pressures that this underconsolidation implies (Johns, this volume).

The very slight arcuate shape of the consolidation curves for these three "underconsolidated" samples is typical of highly disturbed samples (Lambe and Whitman, 1969). Such disturbance could be produced by gas expansion and the accompanying cracks that occurred throughout the upper $260 \mathrm{~m}$ of Site 582 from which these samples were taken. Samples selected for consolidation tests showed minimal disturbance, but it is likely that the disturbance produced both by gas expansion and by the drilling process can account for the apparent underconsolidation of the sediments in Site 582 between 72 and $183 \mathrm{~m}$ sub-bottom.

Two consolidation tests were performed on samples from Site 583. These samples, collected in the hydraulic piston corer from shallow depths (Hole 583A, $23.27 \mathrm{~m}$, 
and Hole 583B, $22.36 \mathrm{~m}$ ) are normally consolidated to slightly overconsolidated (Johns, this volume). The quality of these results is presumed to be high because of the relatively low sampling disturbance produced by the piston corer. Assessing the state of consolidation of deeper portions of the sequence, however, is difficult without additional data.

In contrast to the findings of Leg 87A, Shephard and Bryant (1983), using porosity profiles from Leg 31 for Sites 297 and 298 (Bouma and Moore, 1975) and consolidation tests from Site 298 (Trabant et al., 1975), concluded that the Nankai Trough sediments become highly overconsolidated with increasing depth. This is similar to the earlier findings of the Leg 31 Scientific Party, who concluded that "the rocks of Site 298 are overconsolidated for their present depth of burial indicating that they have been strain hardened by excess stress of tectonic origin" (Ingle, Karig, et al., 1975b). This interpretation is based in part on consolidation tests for which preconsolidation pressures were not obtained because of the highly indurated nature of the sediments. The initial portions of the consolidation curves that were obtained confirm that the sediments are not underconsolidated but do not preclude the interpretation that the deposits are normally consolidated or slightly overconsolidated.

The validity of the consolidation tests can also be questioned because of the stress and strain states employed by the tests. The consolidation test closely reproduces the uniaxial strain that consolidates a sediment on which the only effective applied stress is the weight of the superincumbent strata (Lambe and Whitman, 1969). However, accreted trench sediments are subjected to an additional tectonic component of stress, which raises the mean stress level and generally produces a biaxial or triaxial state of strain. Uniaxial consolidation beyond the in situ state will overestimate the maximum past pressure of a biaxially or triaxially strained sediment, which could lead to an erroneous interpretation of overconsolidation. The tectonically stressed and strained sediments from Site 298 may be in equilibrium with the present mean and deviatoric stress levels and are therefore normally consolidated.

Additional evidence cited by the Leg 31 Scientific Party to support the overconsolidated nature was the "abnormal fissile character" of the sediments. Hole 298 was not continuously cored; thus, pinpointing the first occurrence of physical properties is difficult. However, the first core in which fissility was noted was Core 298-4 (183.5-193.0 m sub-bottom). Fissility was not noted again until Core 298-6 (278.5-288.0 m sub-bottom), although the section between 202.5 and $278.5 \mathrm{~m}$ sub-bottom was not cored. In the sediments of Site 582, the first subhorizontal fissility that continued in successive cores was recorded in Core 582B-23 (260.7-270.3 m sub-bottom). In contrast, at Site 583 the first cores showing subhorizontal fissility consistently were recovered from Core 583D-8 (114.2-124.7 m sub-bottom) and at depths greater than $126.0 \mathrm{~m}$ but less than $198.0 \mathrm{~m}$ in Holes 583,E,F,G (the depth is not well known because of very poor recovery at these depths). When the data from Sites 298, 582, and 583 are compared, a characterization of abnormal fissility in the sediments of Site 298 seems unjustified.

Neither the porosity profiles nor the consolidation tests from Sites 582 and 583 substantiate earlier interpretations of highly overconsolidated sediments in the toe of the Nankai prism. These new data suggest that at shallow depths the sediments are approximately normally consolidated or perhaps slightly overconsolidated and show little anomalous dewatering produced by tectonic stresses. The porosity of these sequences is similar to other sections of turbidites and reflects water loss resulting from normal sedimentation and burial. Reevaluation and comparison of the Leg 31 data with the Leg $87 \mathrm{~A}$ results also confirm these conclusions.

\section{Association of Deformation and Dewatering}

\section{Observations of Spatial Variation of Porosity}

The porosity-depth profiles from Sites 582, 583, and 298 illustrate that at shallow depths any arcward increase in porosity-depth gradient must be very gradual. These data, however, illustrate little about what happens at greater depth within the toe of this accreting prism where thrusting has thickened the sediment section.

In a study based on the velocity structure across the Nankai accretionary wedge, Bray and Karig (1985) have shown that average porosities of columns of sediment decrease arcward. They document an overall large reduction in porosity in comparison to the basinal sequences that enter the prism. Throughout these accreted sediments the porosity-depth gradient is higher than in equivalent basinal sections. In addition this gradient increases gradually arcward.

\section{Processes of Dewatering}

Interpretations of physical properties data from Legs 31 and $87 \mathrm{~A}$, together with seismic reflection profiles across the toe of the Nankai accretionary prism (Bray and Karig, 1985; Karig, this volume), suggest that the dewatering of tectonically deformed sediments results from three processes: uniaxial consolidation induced by slope sedimentation and tectonic thickening, diffuse prefailure shear deformation under multiaxial strain, and heterogeneous deformation at high postfailure strains along major shear zones.

Dewatering in response to fluid pressure gradients produced by overburden loading during sedimentation is common in basinal as well as accreted sections. This process is accelerated in accreted sediments where tectonic thickening drastically increases overburden pressures. The loss of water results in uniaxial (vertical) strain or consolidation of the sequence. Porosity profiles from Sites 298,582 , and 583 suggest that this normal gravitational consolidation induces most of the water loss in the toe of the Nankai prism. On a larger scale, gravitational consolidation is also believed to cause an overall large arcward decrease in average porosities of columns of sediments in the Nankai prism (Bray and Karig, 1985).

Diffuse deformation occurs as tectonic stress increases the horizontal component of stress as well as the mean 
stress exerted on a sediment mass at a given sub-bottom depth. Under these stress conditions prefailure strain is biaxial or triaxial and has been shown to produce preferred fabric orientations (Kézdi, 1974), accompanied by accelerated dewatering (Schofield and Wroth, 1968). Diffuse prefailure deformation is imaged on the seismic reflection profiles as tectonically thickening beds in the protothrust zone and within the seaward-most thrust sheets (Karig, this volume). Total water loss produced by this method is probably small in the toe of the prism. However, the slightly lower porosity and higher shearstrength gradients measured in the upper portions of Sites 583 and 298 relative to the gradients of Site 582 are probably produced by this mechanism. As mentioned previously, this arcward increase of the porosity-depth gradient, relative to that of the undeformed sediment sequence, continues gradually throughout the prism (Bray and Karig, 1985).

Heterogeneous deformation at failure and postfailure conditions may cause localized zones of intense dewatering associated with discrete zones of displacement. This supposition is supported by very limited geologic data to date. However, soil mechanics experimentation demonstrates the efficacy of triaxial shear strain in reducing porosity.

The mechanism proposed to produce localized tectonic dewatering or postyield reduction in porosity is called "shear dewatering" in order to differentiate it from dewatering associated with diffuse deformation (Karig, in press). This mechanism is initiated when deviatoric stresses of tectonic origin cause yield within discrete zones. After failure, deformation is preferentially taken up along these discontinuities, producing local zones of very high strain. Within these zones of heterogeneous deformation, the rotation of platey minerals into a preferred orientation, which is initiated during prefailure deformation, continues after failure and is presumed to accelerate the observed dewatering (Kézdi, 1974). The process of "shear dewatering" suggests that zones of shear failure, such a fault zones, should be regions of decreased porosity and accelerated dewatering.

A possible example of this "shear dewatering" is provided by the exceptionally strong seismic images of several thrust faults at the toe of the Nankai prism (Nasu et al., 1982). Early termination of Holes 583F and 583G precluded direct measurement of the physical properties within and adjacent to the frontal thrust zone, which is perhaps the most intensely deformed and dewatered zone in the toe of the wedge. We did not find any consistent lithologic change that would give rise to the impedance contrast required to produce these reflections.

There are two contradictory hypotheses proposed to explain the nature and cause of the impedance contrasts. The fundamental topic of debate is the sign of the impedance contrast. Those favoring a negative contrast suggest that a reversal in the impedance gradient results from a high fracture porosity in the brecciated sediments within the fault zone. The high fluid content of the zone would reduce both the bulk density and seismic velocity which would lower the impedance of the zone. Positive impedance contrasts could be produced where deforma- tion associated with the thrusting results in a decrease of porosity and an increase of seismic velocity within the fault zone.

On Profile N55-3-1 across the toe of the Nankai prism (Nasu et al., 1982), the polarity of the seismic pulse is complicated by the seismic processing techniques. Before migration, the fault plane reflector is diffracted and difficult to identify. A comparison of migrated time sections, displayed with normal and reverse polarity, indicates that the strongest pulse associated with the fault reflector is the same polarity as the water bottom reflector and the reflector marking the top of the lower Pliocene turbidite sequence directly beneath the hemipelagics of the Shikoku Basin. This interpretation suggests that the fault reflector is the image of a positive impedance contrast. A color plot of instantaneous phase (Aoki, unpublished data) supports this conclusion.

Further evidence for the association of preferential dewatering with zones of deformation in accretionary prisms is drawn from the northern Middle America arc. In a study of the geotechnical properties of forearc sediments off southern Mexico, Shephard and others (1981) concluded that deformation beneath the lower trench slope was not pervasive and had not significantly reduced porosity at shallow depths. However, at depths between 210 and $250 \mathrm{~m}$ sub-bottom in Hole 448, a zone of anomalously intense deformation is associated with a pronounced minimum in porosity.

The dewatering associated with these three deformation mechanisms can be viewed as additive processes. Dewatering by uniaxial consolidation is presumably occurring throughout the prism wherever overburden loads are increasing and excess pore-water pressures are allowed to dissipate. Where tectonic forces have increased differential and mean stress levels and initiated multiaxial deformation, dewatering will be accelerated. In zones of strong heterogeneous tectonic deformation or shear failure, shear dewatering will be superimposed on the other concurrent processes of dewatering. At this time, however, prediction of occurrence and magnitude of dewatering associated with these processes is difficult because the spatial and temporal distribution and interaction of these dewatering processes appears to be a complex function of interdependent physical properties including lithology, porosity, permeability, shear strength, and applied stress levels.

\section{ACKNOWLEDGMENTS}

The authors would like to thank the crew and technicians of the Glomar Challenger as well as the Leg 87A and B scientific parties for their generous assistance and patient cooperation.

\section{REFERENCES}

Bouma, A. H., and Moore, J. C., 1975. Physical properties in deepsea sediments from the Philippine Sea and Sea of Japan. In Karig, D. E., Ingle, J. C., Jr., et al., Init. Repts. DSDP, 31: Washington (U.S. Govt. Printing Office), 535-568.

Bray, C. J., and Karig, D. E., 1985. Porosity of sediments in accretionary prisms, and some implications for dewatering processes. $J$. Geophys. Res., 90:768-778.

Carson, B., 1977. Tectonically induced deformation of deep sea sediments off Washington and northern Oregon: mechanical consolidation. Mar. Geol., 24:289-307. 
Carson, B., Yuan, J. W., Myers, P. B., Jr., and Barnard, W. P., 1974. Initial deep sea sediment deformation at base of Washington continental slope: a response to subduction. Geology, 11:561-564.

Dahlen, F. A., Suppe, J., and Davis, D., 1984. Mechanics of fold-andthrust belts and accretionary wedges (continued): cohesive coulomb theory. J. Geophys. Res., 89:10,087-10,102.

Davis, D., Suppe, J., and Dahlen, F. A., 1983. Mechanics of foldand-thrust belts and accretionary wedges. J. Geophys. Res., 88: 1153-1172.

Gardner, G. H. F., Gardner, L. W. and Gregory, A. R., 1974. Formation velocity and density - the diagnostic basics for stratigraphic traps. Geophysics, 39:770-780.

Hamilton, E. L., 1971. Prediction of in-situ acoustic and elastic properties of marine sediments. Geophysics, 36:266-284. , 1976a. Variation of density and porosity with depth in deep sea sediments. J. Sed. Petrol., 46:280-300.

1976b. Shear-wave velocity versus depth in marine sediments: a review. Geophysics, 41:985-996.

1978. Sound velocity-density relations in sea-floor sediments and rocks. J. Acoust. Soc. Am., 63:366-377.

Ingle, J. C., Jr., Karig, D. E., et al., 1975a. Site 297. In Karig, D. E., Ingle, J. C., Jr., et al., Init. Repts. DSDP, 31: Washington (U.S. Govt. Printing Office), 275-316.

1975b. Site 298. In Karig, D. E., Ingle, J. C., Jr., et al., Init. Repts. DSDP, 31: Washington (U.S. Govt. Printing Office), 317-350.

Karig, D. E., in press. Physical properties and mechanical state of accreted sediments in the Nankai Trough, S.W. Japan Arc. In Moore, J. C. (Ed.), Synthesis of Structural Fabrics of DSDP Cores from Forearcs: Boulder, Colorado (Geol. Soc. Am. Mem.).

Kézdi, A., 1974. Handbook of Soil Mechanics, Vol. 1 Soil Physics: New York (Elsevier).

Lamb, T. W., and Whitman, R. V., 1969. Soil Mechanics: New York (John Wiley and Sons, Inc.).

Lee, H. J., Olsen, H. W., and von Huene R., 1973. Physical properties of deformed sediments from Site 181. In Kulm, L. D., Von
Huene, R., et al., Init Repts. DSDP, 18: Washington (U.S. Govt. Printing Office), 897-901.

Marlow, M. S., Lee, H. J., and Wright, A. W., 1984. Physical properties of sediment from the Lesser Antilles Margin along the Barbados Ridge: results from Deep Sea Drilling Project Leg 78A. In Biju-Duval, B., Moore, J. C., et al., Init. Repts. DSDP, 78A: Washington (U.S. Govt. Printing Office), 549-558.

Mitchell, J. K., 1976. Fundamentals of Soil Behavior: New York (John Wiley and Sons, Inc.).

Moore, J. C., and Biju-Duval, B., 1984. Tectonic synthesis, Deep Sea Drilling Project Leg 78A: structural evolution of offscraped and underthrust sediment, Northern Barbados Ridge complex. In $\mathrm{Bi}$ ju-Duval, B., Moore, J. C., et al., Init. Repts. DSDP, 78A: Washington (U.S. Govt. Printing Office), 601-621.

Nafe, J. E., and Drake, C. L., 1957. Variations with depth in shallow and deep water marine sediments of porosity, density, and the velocities of compressional and shear waves. Geophysics, 22:523-552.

Nasu, N., Tomoda, Y., Kobayashi, K., Kagami, H., et al., 1982. Multichannel Seismic Reflection Data Across Nankai Trough: Tokyo (Ocean Research Institute, University of Tokyo), IPOD-Japan Basic Data Series, No. 4.

Schofield, A. N., and Wroth, C. P., 1968. Critical State Soil Mechanics: London (McGraw Hill).

Shephard, L. E., and Bryant, W. R., 1983. Geotechnical properties of lower trench inner-slope sediments. Tectonophysics, 99:279-312.

Shephard, L. E., Bryant, W. R., and Chiou, W. A., 1981. Geotechnical properties of Middle America trench sediments, Deep Sea Drilling Project Leg 66. In Watkins, J. S., Moore, J. C., et al., Init. Repts. DSDP, 66: Washington (U.S. Govt. Printing Office).

Trabant, P. K., Bryant, W. R., and Bouma, A. H., 1975. Consolidation characteristics of sediments from Leg 31 of the Deep Sea Drilling Project. In Karig, D. E., Ingle, J. C., Jr., et al., Init. Repts. $D S D P, 31$ : Washington (U.S. Govt. Printing Office), 569-572.

Date of Initial Receipt: 23 July 1984

Date of Acceptance: 2 November 1984 